\title{
Evaluation of Pro-Inflammatory Cytokines Expression in Mouse Splenocyte Cells After Incubation with the Biofield Energy Healing Based Herbomineral Formulation: Influence of the Trivedi Effect ${ }^{\circledR}$
} \author{
Snehasis Jana ${ }^{2, *}$ \\ ${ }^{1}$ Trivedi Global, Inc., Henderson, USA \\ ${ }^{2}$ Trivedi Science Research Laboratory Pvt. Ltd., Bhopal, Madhya Pradesh, India \\ Email address: \\ publication@trivedieffect.com (S. Jana) \\ ${ }^{*}$ Corresponding author
}

Mahendra Kumar Trivedi ${ }^{1}$, Alice Branton ${ }^{1}$, Dahryn Trivedi ${ }^{1}$, Gopal Nayak ${ }^{1}$, Barry Dean Wellborn ${ }^{1}$, Deborah Lea Smith ${ }^{1}$, Dezi Ann Koster ${ }^{1}$, Elizabeth Patric ${ }^{1}$, Jagdish Singh ${ }^{1}$, Kathleen Starr Vagt ${ }^{1}$, Krista Joanne Callas ${ }^{1}$, Olga Mirgalijeva ${ }^{1}$, Sambhu Charan Mondal ${ }^{2}$,

To cite this article:

Mahendra Kumar Trivedi, Alice Branton, Dahryn Trivedi, Gopal Nayak, Barry Dean Wellborn, Deborah Lea Smith, Dezi Ann Koster, Elizabeth Patric, Jagdish Singh, Kathleen Starr Vagt, Krista Joanne Callas, Olga Mirgalijeva, Sambhu Charan Mondal, Snehasis Jana. Evaluation of Pro-Inflammatory Cytokines Expression in Mouse Splenocyte Cells After Incubation with the Biofield Energy Healing Based Herbomineral Formulation: Influence of the Trivedi Effect ${ }^{\mathbb{R}}$. American Journal of Bioscience and Bioengineering. Vol. 4, No. 5, 2016, pp. 49-58. doi: 10.11648/j.bio.20160405.11

Received: November 19, 2016; Accepted: November 30, 2016; Published: December 20, 2016

\begin{abstract}
The use of herbomineral formulations in the healthcare sector has increased due to their high safety and better therapeutic action. A new proprietary herbomineral formulation was formulated with a combination of the herbal root extract ashwagandha and minerals viz. zinc, magnesium, and selenium. The aim of the study was to evaluate the immunomodulatory potential of Biofield Energy Healing (The Trivedi Effect ${ }^{\mathbb{B}}$ ) on the test formulation in splenocytes. The test formulation was divided into two parts; one was the control without the Biofield Energy Treatment, while the other part was defined as the Biofield Energy Treated sample, which received the Biofield Energy Healing Treatment remotely by seven renowned Biofield Energy Healers. The MTT assay showed that the test formulation exhibited safe concentrations up to $1.053 \mu \mathrm{g} / \mathrm{mL}$ with cell viability ranging from $88.19 \%$ to $110.30 \%$ in the Biofield Energy Treated sample. The Biofield Energy Healing significantly enhanced the cell viability as compared with the untreated test formulation. The expression of TNF- $\alpha$ was significantly inhibited by $7.23 \%$ at $1.053 \mu \mathrm{g} / \mathrm{mL}$ in the Biofield Energy Treated test formulation compared with the vehicle control. The level of TNF- $\alpha$ was significantly decreased by $3.90 \%, 11.74 \%, 3.12 \%$, and $9.17 \%$ at $0.001053,0.01053,0.1053$ and 1.053 $\mu \mathrm{g} / \mathrm{mL}$, respectively in the Biofield Energy Treated test formulation compared with the untreated test formulation. Additionally, the expression of IL- $1 \beta$ was significantly reduced by $28.98 \%, 51.23 \%, 53.06 \%, 48.98 \%, 55.71 \%$, and $59.10 \%$ at $0.00001053,0.0001053,0.001053,0.01053,0.1053$, and $1.053 \mu \mathrm{g} / \mathrm{mL}$, respectively in the Biofield Energy Treated test formulation compared with the vehicle control. Further, the Biofield Treated test formulation showed significant reduction of IL-1 $\beta$ by $35.07 \%(p \leq 0.05), 47.46 \%(p \leq 0.05)$, and $57.51 \%(p \leq 0.01)$ at $0.001053,0.1053$, and $1.053 \mu \mathrm{g} / \mathrm{mL}$, respectively compared with the untreated test formulation. Similarly, the MIP-1 $\alpha$ expression was inhibited by the Biofield Energy Treated formulation and showed immunosuppressive activity at $0.00001053,0.0001053,0.001053$, and $0.01053 \mu \mathrm{g} / \mathrm{mL}$ by $19.38 \%$, $24.97 \%, 31.23 \%$, and $25.41 \%$, respectively compared with the vehicle control group. The Biofield Treated test formulation significantly $(p<0.001)$ reduced the MIP- $1 \alpha$ expression by $19.33 \%, 22.57 \%$, and $30.50 \%$ at $0.0001053,0.001053$, and 0.01053 $\mu \mathrm{g} / \mathrm{mL}$, respectively compared with the untreated test formulation. Overall, The Trivedi Effect ${ }^{\circledR}$ - Biofield Energy Healing (TEBEH) significantly down-regulated the pro-inflammatory cytokines and potentiated the immunosuppressive effect of the Biofield Energy Treated test formulation, which can be better utilized for organ transplants, autoimmune diseases, inflammatory disorders, anti-aging, stress management, overall health and quality of life, etc.
\end{abstract}


Keywords: Biofield Energy Healing Treatment, Biofield Energy Healers, The Trivedi Effect ${ }^{\circledR}$, LPS, Pro-inflammatory Cytokines, TNF- $\alpha$, MIP-1 $\alpha$, IL-1 $\beta$

\section{Introduction}

The therapeutic and healing properties of plant extracts have been recognized and utilized worldwide since ancient times. Plant products and their extracts are used in both allopathic health care as well as complementary and alternative health care in order to improve overall health and the immune system $[1,2]$. However, much attention has been focused on discovering herbal products with immunomodulatory activity along with low toxicity and better bioavailability [3]. Many scientific studies have identified immunomodulatory properties within medicinal plants, which can be further potentiated with the addition of some minerals that regulate the immune cells. These types of formulations are commonly defined as herbomineral formulations and are the major target for pharmaceutical companies, commonly identified as phytopharmaceutical products or as dietary supplements. Based on the literature, a new proprietary herbomineral formulation was formulated with a combination of the herb ashwagandha (Withania somnifera) root extract and three minerals viz. zinc, magnesium, and selenium. All of the ingredients comprising the test formulation in this present study possess important activities such as immune-modulating, anti-inflammatory, antioxidant, anti-infective, and anti-viral properties [4-7]. According to scientific studies, ashwagandha effect on biological activity is mainly attributed to the presence of withanolides, and is used in many forms of complementary and alternative medicine therapies [8,9]. Apart from it's more commonly known attributes (such as antibacterial, immunomodulatory and antitumor effects), there has been many clinical and preclinical data that pay respect to its immunomodulatory impact $[4,10]$. Minerals such as selenium, zinc, and magnesium play an important role in modulating the immune system because their synergistic impact has been well-defined [5]. Scientific research has documented that in the presence of minerals, herbal medicines have been found to exhibit a high level of phagocytic index and improved antibody titer [11]. These formulations can be used for better therapeutic effect in immune compromised patients affected with cardiovascular diseases, age and stress related diseases, cancer, and autoimmune disorders. Along with the herbomineral formulations, the Biofield Energy Healers in this study have used Energy Medicine (Biofield Energy Healing Treatment) as a complementary and alternative approach to study the impact of Biofield Energy Treatment on the herbomineral formulation for its immunomodulatory potential with respect to the pro-inflammatory cytokines in splenocyte cells isolated from mice.

In recent years, several scientific reports along with clinical trials have demonstrated the beneficial effects of
Biofield Energy Treatments, which have shown enhanced immune function in cases of cervical cancer patients with therapeutic touch [12] and massage therapy [13], etc. Biofield Energy Healing is a recognized complementary and alternative therapy that comes under the category of Energy Medicine. Complementary and Alternative Medicine (CAM) consist of therapies, medicines and practices that are recognized by The National Center for Complementary and Integrative Health $(\mathrm{NCCIH})$ that include, but are not limited to, yoga, meditation, mindfulness, progressive relaxation, guided imagery, natural products, naturopathy, homeopathy, deep breathing, Tai Chi, Qi Gong, Reiki, healing touch, chiropractic/osteopathic manipulation, cranial sacral therapy, massage, special diets, acupuncture, acupressure, relaxation techniques, hypnotherapy, rolfing structural integration, movement therapy, pilates, traditional Chinese herbs and medicines, Ayurvedic medicine, essential oils, aromatherapy, and applied prayer (as is common in all religions like Buddhism, Christianity, Hinduism and Judaism). Human Biofield Energy has subtle energy that has the capacity to work in an effective manner [14]. Reports show that Complementary and Alternative Medicine (CAM) therapies have been practiced worldwide with reported clinical benefits in different health disease profiles [15]. This energy can be harnessed and transmitted by individuals into living and nonliving things via the process of Biofield Energy Healing. Biofield Energy Treatment (The Trivedi Effect ${ }^{\mathbb{A}}$ ) has been extensively studied with significant outcomes in many scientific fields such as cancer research $[16,17]$, altering the antimicrobial sensitivity of pathogenic microbes in microbiology [18-21], genetics [22, 23], altering the structural, thermal, physical and chemical properties of pharmaceutical compounds [24-27], improving overall growth, productivity, quality and yield of plants in agricultural science [28-31], and in changing the structure of the atom in relation to various metals, ceramics, polymers and chemicals in materials science [32-35]. The authors of this study sought to evaluate the impact of Biofield Energy Treatment (The Trivedi Effect ${ }^{\mathbb{B}}$ ) on the specified herbomineral formulation, which might improve the immunomodulatory function of mice splenocyte cells in an in vitro cellular model.

\section{Materials and Methods}

\subsection{Chemicals and Reagents}

3-(4, 5-diamethyl-2-thiazolyl)-2, 5-diphenyl-2Htetrazolium) (MTT), lipopolysaccharide (LPS), L-glutamine, Roswell Park Memorial Institute (RPMI)-1640, penicillin, 4(2-hydroxyethyl)-1-piperazineethanesulfonic acid (HEPES), streptomycin, 2- mercaptoethanol were purchased from Sigma Chemical Corp. (St. Louis, MO), a subsidiary of 
Sigma-Aldrich Corporation. ELISA (enzyme-link immunosorbent assay) kits for all cytokines such as tumor necrosis factor alpha (TNF- $\alpha$ ), macrophage inflammatory protein-1 $\alpha$ (MIP-1 $\alpha)$, and interleukin-1 beta (IL-1 $\beta$ ) were purchased from R\&D Systems, USA. Fetal bovine serum (FBS) was procured from GIBCO, USA. Ashwagandha root extract powder was procured from Sanat Products Ltd., India. Zinc chloride and magnesium (II) gluconate hydrate were procured from Tokyo Chemical Industry Co., Ltd. (TCI), Japan. Sodium selenate was procured from Alfa Aesar, USA. Rapamycin, sodium bi-carbonate $\left(\mathrm{NaHCO}_{3}\right)$, and ethylene diamine tetra acetic acid (EDTA) were procured from Sigma. All the other chemicals used in this experiment were of analytical grade and procured from local vendors in India. LPS was used as an immunostimulant. Concanavalin A and rapamycin were used as a reference standard (positive controls) in splenocyte culture.

\subsection{Test Formulation and Reference Standard}

The test herbomineral formulation contained a combination of four ingredients: ashwagandha root powder extract, zinc chloride, sodium selenite, and magnesium gluconate. LPS was used as an inflammatory stimulant, while Con-A and rapamycin were used as a reference standard (positive control) for immunostimulatory and immunosuppressive action, respectively in splenocytes assay.

\subsection{Experimental Animal}

C57BL/6 male mice ( 8 weeks old, 22 gm body weight) were purchased from Vivo Bio Tech Ltd., Hyderabad, India and acclimatized for one week prior to the experiments. The mice were maintained under controlled conditions with a temperature of $22 \pm 3^{\circ} \mathrm{C}$, humidity of $30 \%$ to $70 \%$ and a 12 hour light/12-hour dark cycle and laboratory rodent diet and drinking tap water were provided ad libitum. All the procedures were in strict accordance with the Guide for the Care and Use of Laboratory Animals published by the US National Institutes of Health (NIH). The approval of the Institutional Animal Ethics Committee (IAEC) was obtained prior to carrying out the animal experiment.

\subsection{Biofield Energy Healing Strategies}

The herbomineral formulation was divided into two parts. One part was considered the control formulation and the other part was defined as the treated formulation. The treated test formulation was subjected to the Biofield Energy Healing (also known as The Trivedi Effect ${ }^{\circledR}$ ) of seven Biofield Energy Healers and kept under strict, standard laboratory conditions. The Biofield Energy Treatment was provided for 5 minutes by the group of seven Biofield Energy Healers (The Trivedi Effect ${ }^{\circledR}$ ), who were all remotely located in the U.S.A. The treated herbomineral formulation was located in the research laboratory of Dabur Research Foundation near New Delhi in Ghaziabad, India. None of the Biofield Energy Healers in this study visited the laboratory in person, nor had any contact with the herbomineral samples.
Similarly, the control formulation was subjected to a "sham" healer under the same laboratory conditions for 5 minutes. The sham healer did not have any knowledge about the Biofield Energy Treatment. After that, the Biofield Energy Treated and the untreated samples were kept in similar sealed conditions until they were used for an estimation of various cytokines as per the study design.

\subsection{Experimental Design}

The experimental study was divided into 7 groups. Group 1 comprised of the splenocyte cells without LPS and was denoted as the negative control. Group 2 served as a stimulant group that included cells with LPS. Group 3 included the splenocyte cells with LPS along with the vehicle $(0.005 \%$ DMSO) and was denoted as the vehicle control. Groups 4 and 5 were defined as the positive control, which included cells with Con-A $(0.5 \mu \mathrm{g} / \mathrm{mL})$ and rapamycin $(1 \mathrm{nM}$ and $10 \mathrm{nM})$, respectively. Groups 6 and 7 were denoted as the test item groups that included splenocyte cells with LPS along with the untreated and the Biofield Energy Treated test formulations, respectively, at 0.00001053 to $10.53 \mu \mathrm{g} / \mathrm{mL}$. After 48 hours of incubation, supernatants were analyzed for the secreted levels of TNF- $\alpha$, MIP- $1 \alpha$, and IL- $1 \beta$ using ELISA as per the manufacturer's instructions. Concentrations were determined in triplicate wells of each sample.

\subsection{Isolation of Murine Splenocytes}

C57BL/6 male mice were sacrificed and the spleens were removed and ground by passing through a sterile plastic strainer under aseptic conditions. After that, the cells were centrifuged twice at $1000 \mathrm{~g}$ for 5 minutes. Erythrocytes were lysed by a lysis buffer $\left(0.15 \mathrm{M} \mathrm{NH}_{4} \mathrm{Cl}, 0.01 \mathrm{M} \mathrm{NaHCO}_{3}\right.$, and $0.1 \mathrm{mM}$ EDTA, pH 7.4) and then the cell pellets were washed twice with RPMI-1640 medium. Then the cells were resuspended in a fresh complete RPMI-1640 medium (RPMI 1640 medium plus $10 \%$ FBS, 2 mM glutamine, streptomycin and $100 \mathrm{IU} / \mathrm{mL}$ of penicillin and $15 \mathrm{mM}$ HEPES, and $50 \mathrm{mM}$ 2-mercaptoethanol). The cell counts were performed with the help of a hemocytometer and cell viability was determined using the trypan-blue dye exclusion technique and the results showed $\geq 80 \%$ of viable cells. The cells were cultured in 96well tissue culture plates with $0.2 \times 10^{6}$ cells per well. They were incubated at $37^{\circ} \mathrm{C}$ in a humidified atmosphere containing $5 \% \mathrm{CO}_{2}$ for the specified period [36].

\subsection{Cell Culture and Test Formulation Treatment}

The splenocyte $\left(0.2 \times 10^{6}\right.$ cells per well $)$ cells were grown in 96-well culture plates using RPMI-1640 medium supplemented with $10 \%$ FBS, $100 \mu \mathrm{g} / \mathrm{mL}$ of streptomycin, and 100 units $/ \mathrm{mL}$ of penicillin. The LPS $(0.5 \mu \mathrm{g} / \mathrm{mL})$ induced splenocyte cells cultures were grown for 48 hours at $37^{\circ} \mathrm{C}$ in a humidified $\mathrm{CO}_{2}$ incubator $\left(5 \% \mathrm{CO}_{2}\right)$. The effect of cytotoxicity was determined by exposing cells to different concentrations of the test formulation in a RPMI-1640 medium. Various concentrations of the test formulation from $0.00001053 \mu \mathrm{g} / \mathrm{mL}$ to $10.53 \mu \mathrm{g} / \mathrm{mL}$ were used in splenocytes 
culture. The respective vehicle control kept in the assay was DMSO.

\subsection{Cytotoxicity by MTT Assay}

The effects of the Biofield Energy Treated and untreated test formulations at the concentration range of 0.00001053 $\mu \mathrm{g} / \mathrm{mL}$ to $10.53 \mu \mathrm{g} / \mathrm{mL}$ were tested for cell viability using 3(4,5-dimethythiazol-2-yl)-2,5-diphenyl tetrazolium bromide (MTT) assay. The number of viable cells was determined by the ability of the mitochondria to convert MTT to formazan dye. Splenocyte cells were cultured overnight in 96-well plates, at a density of $0.2 \times 10^{6}$ cells per well. After treatment with the test formulation and incubation period, the medium was removed. $20 \mu \mathrm{L}$ of $5 \mathrm{mg} / \mathrm{mL}$ MTT was then added to each well and incubated for 3 hours further at $37^{\circ} \mathrm{C}$ in a humidified 5\% $\mathrm{CO}_{2}$ atmosphere. The cells were centrifuged and supernatants were removed. The cell pellet in each well was resuspended in $150 \mu \mathrm{L}$ of DMSO to dissolve formazan crystals. The optical density of each well was read at $540 \mathrm{~nm}$ using a BioTek Reader (SIAFRT/Synergy HT multimode reader, US).

The effect of the test formulation on the cell viability of splenocyte cells was determined as per the equation (1):

$$
\% \text { Cell viability }=100-\% \text { cytotoxicity }
$$

Where; \% cytotoxicity $=[($ O.D. of control cells - O.D. of the cells treated with the test formulation)/O.D. of control cells $]^{*} 100$.

The concentrations that resulted in $>75 \%$ viability were selected for subsequent cytokine estimation.

\subsection{Determination of Cytokines (TNF- $\alpha$ and IL-1B) and Chemokine (MIP-1a) Using ELISA}

The in vitro activities of the Biofield Energy Treated and untreated test formulations were estimated in the mice splenocytes for the production of TNF- $\alpha$, MIP- $1 \alpha$, and IL-1 $\beta$ using enzyme-linked immunosorbent assay (ELISA). The ELISA plates were coated with an antibody in a coating buffer at the recommended concentration and kept overnight at $4{ }^{\circ} \mathrm{C}$. After washing with PBS-T (PBS with $0.05 \%$ Tween 20 ), the plates were blocked with assay diluent for at least 2 hours at room temperature. A total of $100 \mu \mathrm{L}$ culture supernatant from different experimental samples and standards were incubated overnight at $4{ }^{\circ} \mathrm{C}$ and, after three washes, biotinylated anti-mice cytokine (TNF- $\alpha, \mathrm{MIP}-1 \alpha$, and IL-1 $\beta$ ) antibodies at the recommended concentrations were incubated for 1 hour at room temperature and the plate was incubated for 45 minutes at room temperature with gentle shaking. The plates were again washed 3 times and then $100 \mu \mathrm{L}$ of horseradish per-oxidase (HRP)-streptavidin conjugate solution was added and the plate was incubated for 45 minutes at room temperature with gentle shaking. Next, the plate wells were washed 3 times as per the previous methods and $100 \mu \mathrm{L}$ of 3,3,5,5'-tetramethylbenzidine (TMB) one-step substrate reagent was added, followed by a 30minute incubation at room temperature in the dark. Further,
$50 \mu \mathrm{L}$ of $0.2 \mathrm{~mole} / \mathrm{L}$ sulphuric acid was added to each well to stop the reaction and the plates were read for absorbance at $450 \mathrm{~nm}$ using a BioTek Reader (SIAFRT/Synergy HT multimode reader). Standards were run in parallel to the samples, and the concentrations were determined in triplicates for each sample [37].

\subsection{Statistical Analysis}

Data were expressed as mean \pm standard error of mean (SEM) and were subjected to one-way analysis of variance (ANOVA) followed by Dunnett's test for multiple comparison and Student's $t$-test for two groups comparison. Statistical significance was considered at $p \leq 0.05$.

\section{Results}

\subsection{MTT Assay on Splenocyte Cells}

The effect of the Biofield Treated and untreated test formulations on the proliferation of mice splenocyte cells was examined after 48 hours through MTT cell viability assay. The effect of the test formulation on the viability of the splenocytes is shown in Figure 1. The results showed the \% cell viability was altered after the Biofield Treatment in the tested concentration of the test formulation. The untreated, LPS, and Con-A group showed 100\%, 171.7\%, and 201.9\% cell viability, respectively. The vehicle control group reported with $100 \%$ and the rapamycin group reported with $98.9 \%$ and $89.9 \%$ at concentrations 1 and $10 \mathrm{nM}$, respectively. The increased cell viability with respect to the vehicle control might be due to proliferation in the cell culture. Con-A and rapamycin showed immunostimulatory and immunosuppressive action, respectively and used as the positive control in the experiment. Concentration ranges from 0.00001053 to $10.53 \mu \mathrm{g} / \mathrm{mL}$ was selected for comparison of cell viability after adding the Biofield Treated and untreated test formulations to the splenocyte cells. The test formulation was found safe at concentrations up to $1.053 \mu \mathrm{g} / \mathrm{mL}$ with percentage viability ranging from $88.19 \%$ to $110.30 \%$. The cell viability was greatly decreased at the concentration of $10.53 \mu \mathrm{g} / \mathrm{mL}$ in both the Biofield Energy Treated (38.24\%) and untreated formulations $(26.12 \%)$, so this concentration was not selected for the estimation of cytokines. However, at three tested concentrations the Biofield Energy Treated test formulation showed increased cell viability, i.e. at 0.0001053 , 0.001053 , and $0.01053 \mu \mathrm{g} / \mathrm{mL}$ by $10.09 \%, 8.90 \%$, and $10.30 \%$, respectively as compared to the vehicle control group. The percentage of increased cell viability in the Biofield Energy Treated test formulation was $19.95 \%$ and $46.40 \%$ at 0.1053 and $10.053 \mu \mathrm{g} / \mathrm{mL}$, respectively as compared to the untreated test formulation. In addition, the cell viability was also increased at the concentration of $0.0001053,0.001053,0.01053$, and $1.053 \mu \mathrm{g} / \mathrm{mL}$, while it decreased at $0.00001053 \mu \mathrm{g} / \mathrm{mL}$ in the Biofield Energy Treated test formulation as compared to the untreated test formulation. Overall, the results showed the cell viability was significantly altered after the Biofield Energy Treatment. 


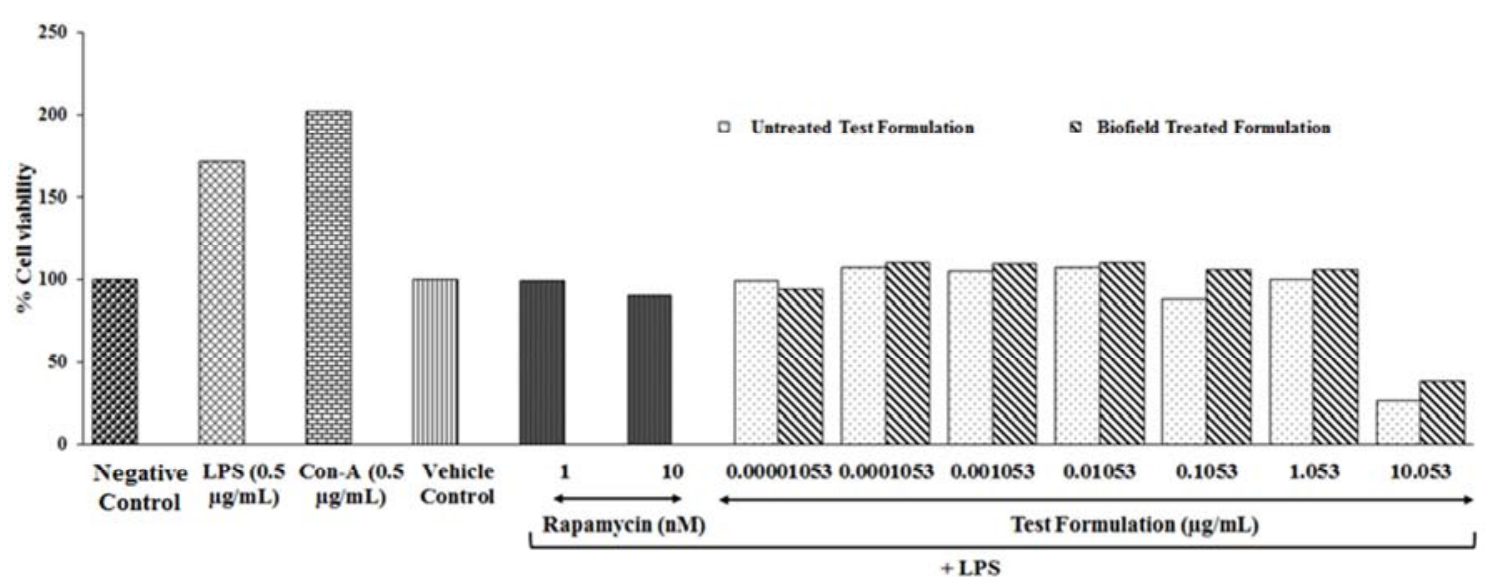

Figure 1. MTT assay in splenocyte cells after 48 hours of treatment with various concentrations of the test formulation in the presence of $0.5 \mu \mathrm{g} / \mathrm{mL}$ of LPS. The absorbance of the MTT formazan was determined at $540 \mathrm{~nm}$ in an ELISA reader. Cell viability was defined as the absorbance ratio (expressed as a percentage) of the test formulation treated cells relative to the untreated vehicle control group.

\subsection{Effect of the Test Formulation on the Expression of Pro-inflammatory Cytokines (TNF- $\alpha$ and IL-1B) and Chemokine (MIP-1a) in Splenocyte Cells}

Lymphocyte proliferation and the activation of natural killer (NK) cells are cytokine dependent [38]. The effect of the Biofield Treated herbomineral test formulation was observed on pro-inflammatory cytokines TNF- $\alpha$, MIP- $1 \alpha$, and IL-1 $\beta$. All play major roles in inflammation, immune modulation, and lymphocyte activation, so it might be expected that the herbomineral test formulation can modulate the expression and activation of cytokines. Therefore, the expression of TNF- $\alpha$, MIP- $1 \alpha$ and IL- $1 \beta$ at six concentrations was examined in the spleen cells. The effect of the test formulation on pro-inflammatory cytokines was estimated by incubating the formulation with various concentrations of the treated and untreated test formulations for 48 hours using ELISA assay.

\subsubsection{Assessment of TNF- $\alpha$ Expression}

The splenocyte cells were treated with the Biofield Energy Treated and untreated test formulations at non-cytotoxic concentrations $(0.00001053$ to $1.053 \mu \mathrm{g} / \mathrm{mL})$ for 48 hours. The effect of the test formulation on TNF- $\alpha$ secretion in splenocyte cells is shown in Figure 2. The negative control

untreated Test Formulation (untreated cells), LPS, Con-A, and vehicle control group showed TNF- $\alpha$ values as $87.60,504.65,271.32$, and 501.55 $\mathrm{pg} / \mathrm{mL}$, respectively. The Biofield Energy Treated test formulation showed an increment of TNF- $\alpha$ expression by $11.36 \%, 11.98 \%$, and $10.28 \%$ at $0.00001053,0.0001053$, and $0.1053 \mu \mathrm{g} / \mathrm{mL}$, respectively as compared to the vehicle control group. However, at $1.053 \mu \mathrm{g} / \mathrm{mL}$ the expression of TNF- $\alpha$ was decreased by $7.23 \%$ as compared to the vehicle control group. Additionally, the untreated test formulation showed an increment of TNF- $\alpha$ expression by $10.82 \%$, $15.15 \%$, and $13.83 \%$ at $0.001053,0.01053$, and 0.1053 $\mu \mathrm{g} / \mathrm{mL}$, respectively as compared to the vehicle control group. However, in the rest of the tested concentrations $(0.00001053,0.0001053$, and $1.053 \mu \mathrm{g} / \mathrm{mL})$ the expression of TNF- $\alpha$ was minimally increased as compared to the vehicle control group. Overall, the Biofield Energy Treated test formulation showed the expression of TNF- $\alpha$ was significantly decreased by $3.90 \%, 11.74 \%, 3.12 \%$, and $9.17 \%$ at $0.001053,0.01053,0.1053$, and $1.053 \mu \mathrm{g} / \mathrm{mL}$, respectively as compared to the untreated test formulation. The expression of TNF- $\alpha$ was increased in the Biofield Energy Treated test formulation by $4.88 \%$ and $7.65 \%$ at 0.00001053 and $0.0001053 \mu \mathrm{g} / \mathrm{mL}$, respectively as compared to the untreated test formulation (Figure 2).

Biofield Treated Formulation

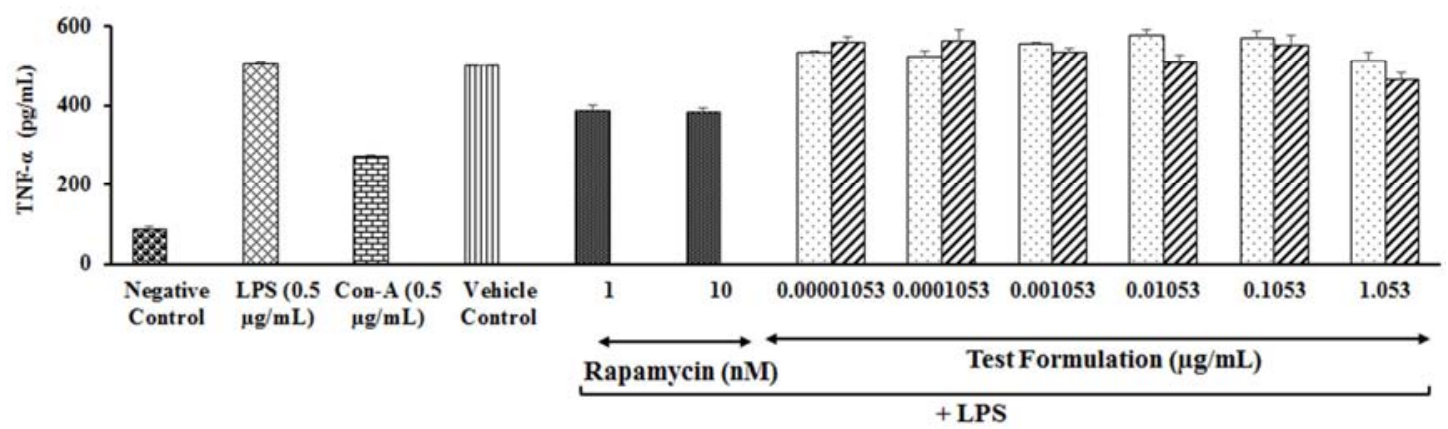

Figure 2. The effect of test formulation on cytokine TNF- $\alpha$. For each concentration treatment, the level of TNF- $\alpha$ release was measured after 48 hours of treatment. The values are represented as mean \pm SEM. 


\subsubsection{Estimation of IL-1/ Expression}

The effects of the Biofield Energy Treated and untreated test formulations on IL-1 $\beta$ secretion in splenocyte cells are shown in Figure 3. Both the untreated and Biofield Energy Treated test formulations demonstrated inhibition of IL-1 $\beta$ as compared to the LPS induced group. However, the Biofield Energy Treated test formulation exhibited better suppression than the untreated test formulation at 3 concentrations, which indicated that the Biofield Energy Healing enhanced the test formulation's immunosuppressive properties. The IL- $1 \beta$ expression showed significant reduction by $28.98 \%, 51.23 \%, 53.06 \%$, $48.98 \%, 55.71 \%$, and $59.10 \%$ at $0.00001053,0.0001053$, $0.001053,0.01053,0.1053$, and $1.053 \mu \mathrm{g} / \mathrm{mL}$, respectively

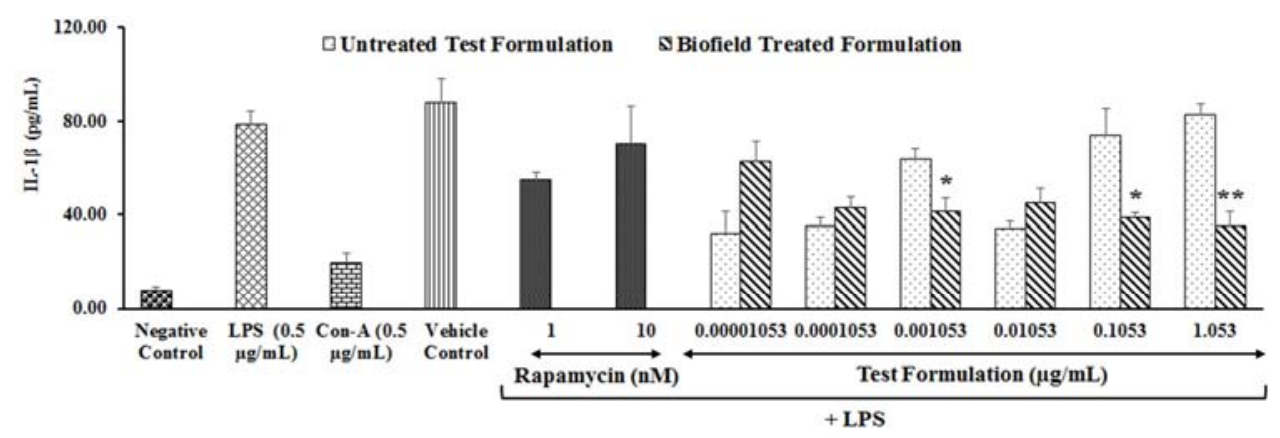

Figure 3. The effect of the LPS mediated production of IL-1 $\beta$ by the test formulation. For each concentration treatment, the level of IL-1 $\beta$ release was measured after 48 hours of treatment. The values are represented as mean $\pm S E M$. ${ }^{*} p \leq 0.05$ and $* * p \leq 0.01$ (as compared to the untreated test formulation).

\subsubsection{Estimation of MIP-1a Expression}

The effects of the Biofield Energy Treated and untreated test formulations on MIP- $1 \alpha$ secretion in splenocyte cells are shown in Figure 4. The negative control (untreated cells), LPS, Con-A, and vehicle control group showed values of MIP- $1 \alpha$ as $42.8 \pm$ $14,598.6 \pm 11.2,285.5 \pm 10.3$, and $768.0 \pm 10.2 \mathrm{pg} / \mathrm{mL}$, respectively. Both the untreated and Biofield Energy Treated test formulations demonstrated inhibition of MIP-1- $\alpha$ as compared to the LPS stimulated group. Moreover, the Biofield Energy Treatment enhanced the immunosuppressive property of the test formulation at 3 concentrations. This indicated that the Biofield Energy Treated test formulation showed more inhibition than the untreated test formulation. The results showed the Biofield Energy Treated test formulation significantly reduced the MIP$1 \alpha$ expression by $19.38 \%, 24.97 \%, 31.23 \%$, and $25.41 \%$ at in the Biofield Energy Treated test formulation as compared to the vehicle control group. Further, the level of IL- $1 \beta$ was significantly reduced by $63.41 \%, 60.19 \%, 27.72 \%, 60.99 \%$, $15.70 \%$, and $5.64 \%$ at $0.00001053,0.0001053,0.001053$, $0.01053,0.1053$, and $1.053 \mu \mathrm{g} / \mathrm{mL}$, respectively in the untreated test formulation as compared to the vehicle control. At $0.001053,0.1053$, and $1.053 \mu \mathrm{g} / \mathrm{mL}$ the level of IL-1 $\beta$ was significantly suppressed by $35.07 \%(p \leq 0.05)$, $47.46 \%(p \leq 0.05)$, and $57.51 \%(p \leq 0.01)$, respectively in the Biofield Energy Treated test formulation as compared to the untreated test formulation. However, at the other three concentrations $(0.00001053,0.0001053$, and 0.01053 $\mu \mathrm{g} / \mathrm{mL}$ ) the expression of IL- $1 \beta$ was increased to some extent as compared to the untreated test formulation.

$0.00001053, \quad 0.0001053, \quad 0.001053$, and $0.01053 \mu \mathrm{g} / \mathrm{mL}$, respectively as compared to the vehicle control group. However, the expression of MIP- $1 \alpha$ was increased by $3.01 \%$ and $14.10 \%$ at 0.1053 and $1.053 \mu \mathrm{g} / \mathrm{mL}$, respectively in the Biofield Energy Treated test formulation as compared to the vehicle control group. The level of MIP- $1 \alpha$ was decreased by $16.80 \%, 7.10 \%$, $11.18 \%, 12.85 \%$, and $9.60 \%$ at $0.00001053,0.0001053$, $0.001053,0.1053$, and $1.053 \mu \mathrm{g} / \mathrm{mL}$, respectively in the untreated test formulation, while the level of MIP- $1 \alpha$ was increased at $0.01053 \mu \mathrm{g} / \mathrm{mL}$ as compared to the vehicle control group. Overall, there was a significant $(p<0.001)$ downregulation of the MIP- $1 \alpha$ expression at the three concentrations $0.0001053,0.001053$, and $0.01053 \mu \mathrm{g} / \mathrm{mL}$ by $19.33 \%, 22.57 \%$, and $30.50 \%$, respectively in the Biofield Energy Treated test formulation as compared to the untreated test formulation.

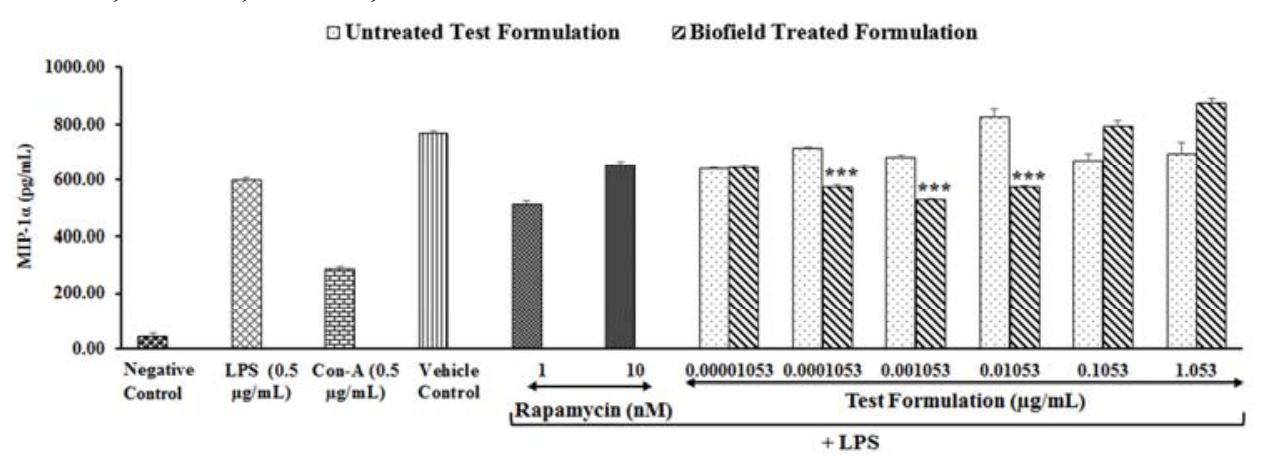

Figure 4. Dose-dependent inhibition of LPS mediated production of MIP-1 $\alpha$ by the test formulation. For each concentration treatment, the level of MIP-1 $\alpha$ release was measured after 48 hours of treatment. The values are represented as mean $\pm S E M . * * * p<0.001$ (as compared to the untreated test formulation). 


\section{Discussion}

Over the last decade, the use of herbomineral formulations and products to maintain, promote and improve overall health has gradually increased throughout the world. Furthermore, herbal extracts and plant products have the capacity to stimulate or modulate the immune system, which can be used to treat autoimmune diseases $[39,40]$. The novel proprietary herbomineral test formulation used in this study consists of a mixture of the herbal root extract ashwagandha and the minerals zinc chloride, magnesium gluconate hydrate, and sodium selenate. Each of the individual components that comprise this formulation have already been proven to have immunomodulatory activity. Ashwagandha has been shown to inhibit TNF- $\alpha$ induced nuclear factorkappa $\mathrm{B}(N F-\kappa B)$ activation in human myelomonoblastic leukemia cells in a study conducted by Singh and Aggrawal [41]. Selenium is an essential trace element that plays an important role in protecting cells from oxidative stress. As a dietary supplement, selenium may reduce the risk of cardiomyopathy, cancer, and immune disorders in humans [42, 43]. Zinc deficiency influences the generation of cytokines, including IL-1 $\beta$, IL-2, IL-6, and TNF- $\alpha$. Plasma cytokines also exhibit a dose-dependent response to zinc supplementation. The mechanism of action may reflect the ability of zinc to induce or inhibit the activation of $N F$ $\kappa B$. The wide involvement of zinc in the immune system [44] includes an ability to influence the production and signaling of numerous inflammatory cytokines in a variety of cell types $[45,46]$. Magnesium sulfate reduced cytokine production in intrapartum women, as well as term and preterm neonates, demonstrating effectiveness in those at risk for inflammation associated adverse perinatal outcomes, whereby magnesium plays a critical regulatory role in $N F-\kappa B$ activation, cytokine production, and disease pathogenesis [47].

TNF- $\alpha$ is not only recognized as a circulating factor that causes necrosis of tumors, but is also identified as a key regulator of the inflammatory response [48]. Literature reports that TNF- $\alpha$ can interact with two different types of receptors, tumor necrosis factor receptor 1 and 2 (TNFR1 and TNFR2), which are differentially expressed in cells and tissues and initiate both distinct and overlapping signal transduction pathways [49]. These diverse signaling cascades lead to a range of cellular responses, which include cell death, survival, differentiation, proliferation, and migration [50]. In this experiment, it is assumed that the down-regulation of cellular response might be accelerated due to the Biofield Energy Healing Treatment to the test formulation.

The cytokine cascade in pain and inflammatory processes is a tremendously complex system, involving glial, immune, and neuronal cell interactions [51]. The IL-1 $\beta$ is a proinflammatory cytokine that has been implicated in pain, inflammation, and autoimmune conditions [52, 53]. Inflammation is the first response of the immune system to infection or irritation. It is caused by cytokines such as TNF$\alpha$, IL-1, and IL- 6 by eicosanoids such as prostaglandin E2
(PGE2) [54]. Thus, inhibitors of these cytokines have been considered as candidates for anti-inflammatory drugs. The evaluation of immune cells, especially splenocyte cells, is always used to screen the potential immunomodulatory effect of a substance/product. These immune cells then migrate to the spleen, which is the secondary lymphoid tissue, and respond to antigens there. Therefore, the regulation of thymus and spleen cell proliferation, which is closely related to the maintenance of immune homeostasis, can be considered as important markers for immune response control. Lymphocytes/monocytes/macrophages are key mediators of inflammation and are widely distributed in the body [55]. Therefore, splenocyte cells represent appropriate model systems to study immune responses, and thus was utilized to investigate the anti-inflammatory effects of the newly developed proprietary herbomineral product in this present study. Based on the literature, it has been shown that human emotions like loneliness are directly correlated with the down-regulation of genes bearing anti-inflammatory response elements and the up-regulation of genes bearing response elements for pro-inflammatory $N F-\kappa B /$ Rel transcription factors [56]. Cole et al. (2007), reported that the human genome-wide transcriptional activity is altered in association with a social epidemiological risk factor like loneliness. An impaired transcription of glucocorticoid response genes and increased activity of pro-inflammatory transcription control pathways provide a functional genomic explanation for the elevated risk of inflammatory disease in individuals who experience chronically high levels of subjective social isolation [57].

In this study, the cytotoxic effect of the Biofield Energy Treated test formulation was screened by assessing the metabolic activity of immune cells through MTT assay. MTT assay is more rapid, less costly, less time-consuming, nonradioactive and is proven to be accurate in determining the relation between the metabolic activity and cell growth [58]. This test is widely used in the in vitro evaluation of the toxicity of any test item [59]. The anti-inflammatory effects of both the Biofield Energy Treated and untreated test formulations were evaluated in mice splenocyte cells. The metabolic activity is evaluated by measuring the activity of the mitochondrial enzyme succinate dehydrogenase using the MTT test. The splenocytes (immune cells) were exposed at 0.00001053 to $10.053 \mu \mathrm{g} / \mathrm{mL}$ of the test formulation for 48 hours. The splenocyte cells showed cytotoxicity at 10.053 $\mu \mathrm{g} / \mathrm{mL}$ of the test formulation. The test formulation demonstrated the greatest potential for modulating the inflammatory response of splenocyte cells in vitro assay. There was a significant reduction of TNF- $\alpha$, IL- $1 \beta$, and MIP$1 \alpha$ levels in the supernatants of most of the tested concentrations. Several cytokines are deeply associated with inflammatory diseases. In particular, TNF- $\alpha$ and IL-1 $\beta$ are prominent contributors to chronic inflammatory disorders. The TNF- $\alpha$ and IL- $1 \beta$ receptor antagonists have been clinically successful in improving the symptoms of RA patients [60]. Steroids such as prednisolone and 
dexamethasone are known to reduce the production of these cytokines [61]. Our data suggest that the test formulation modulates the splenocytes' function. The Biofield Energy Treated test formulation strongly inhibited the proinflammatory cytokines TNF- $\alpha$, MIP-1 $\alpha$, and IL-1 $\beta$. Therefore, these results suggest that the test formulation may inhibit the inflammatory responsiveness of splenocytes by modulating the signal transduction pathways. This effect may be the result of specific inhibition of $N F-\kappa B$, a transcription factor involved in the activation of many inflammatory mediator genes. Due to its immunomodulatory effects, the Biofield Energy Treated herbomineral test formulation may prove to be an innovative strategy to affect the immune system and to help combat various diseases.

\section{Conclusions}

The study results suggest that the Biofield Energy Treated test formulation showed better and significant inhibition of pro-inflammatory cytokines (TNF- $\alpha$ and IL-1 $\beta$ ) and chemokine (MIP-1 $\alpha$ ) expression as compared to the untreated test formulation in splenocyte cells. The level of TNF- $\alpha$ was significantly decreased by $3.90 \%, 11.74 \%, 3.12 \%$, and $9.17 \%$ at $0.001053,0.01053,0.1053$, and $1.053 \mu \mathrm{g} / \mathrm{mL}$, respectively in the Biofield Energy Treated test formulation as compared to the untreated test formulation. Moreover, the level of IL$1 \beta$ was significantly reduced by $35.07 \%(p \leq 0.05), 47.46 \%$ $(p \leq 0.05)$, and $57.51 \%(p \leq 0.01)$ at $0.001053,0.1053$, and $1.053 \mu \mathrm{g} / \mathrm{mL}$, respectively in the Biofield Energy Treated test formulation as compared to the untreated test formulation. Even further, the expression of MIP- $1 \alpha$ was significantly reduced by $19.33 \% \quad(p<0.001), 22.57 \% \quad(p<0.001)$, and $30.50 \%(p<0.001)$ at $0.0001053,0.001053$, and 0.01053 $\mu \mathrm{g} / \mathrm{mL}$, respectively in the Biofield Energy Treated test formulation as compared to the untreated test formulation. The Trivedi Effect ${ }^{\circledR}$-Biofield Energy Healing (TEBEH) Treatment administered remotely by the seven Biofield Energy Healers enhanced the herbomineral test formulation's anti-inflammatory and immunomodulatory properties without any adverse effect to the animals throughout the exposure period. Overall, the data showed that there was a significant reduction of all three pro-inflammatory mediators in the Biofield Energy Treated test formulation. Through the Biofield Energy Treatment, the test formulation's antiinflammatory and immunomodulatory properties were enhanced. Thus, the Biofield Energy Treated test formulation may act as an effective anti-inflammatory and immunomodulatory product, and it can be used as a Complementary and Alternative Medicine (CAM) to prevent immune-mediated tissue damage in cases of organ transplants (for example kidney transplants, liver transplants and heart transplants), various autoimmune disorders such as Lupus, Systemic Lupus Erythematosus, Addison Disease, Celiac Disease (gluten-sensitive enteropathy), Dermatomyositis, Graves' Disease, Hashimoto Thyroiditis, Multiple Sclerosis, Myasthenia Gravis, Pernicious Anemia, Aplastic Anemia, Reactive Arthritis, Rheumatoid Arthritis, Sjogren Syndrome,
Type 1 Diabetes, Alopecia Areata, Crohn's Disease, Fibromyalgia, Vitiligo, Psoriasis, Scleroderma, Chronic Fatigue Syndrome and Vasculitis, as well as inflammatory disorders such as Asthma, Irritable Bowel Syndrome (IBS), Ulcerative Colitis, Parkinson's Disease, Alzheimer's Disease, Atherosclerosis, Dermatitis, Diverticulitis, Hepatitis, and stress etc. Further, the Biofield Energy Healing Treated test formulation can also be used in the prevention of immunemediated tissue damage in cases of organ transplants (for example heart transplants, kidney transplants and liver transplants), for anti-aging, stress prevention and management, and in the improvement of overall health and quality of life.

\section{Abbreviations}

LPS: Lipopolysaccharide, DMSO: Dimethyl sulfoxide, FBS: Fetal bovine serum, MTT: 3-(4,5-Dimethylthiazol-2yl)-2,5-Diphenyltetrazolium Bromide, PBS: Phosphate buffer saline, ELISA: Enzyme-linked immunosorbent assay

\section{Acknowledgements}

The authors of this study are thankful to Dabur Research Foundation, Trivedi Global, Inc., Trivedi Science, and Trivedi Master Wellness for their support throughout this work.

\section{References}

[1] Thomson GE (2007) The Health Benefits of Traditional Chinese Plant Medicines: Weighing the Scientific Evidence: A Report for the Rural Industries Research and Development Corporation, RIRDC, Barton, Australia.

[2] Rishton GM (2008) Natural products as a robust source of new drugs and drug leads: Past successes and present day issues. Am J Cardiol 101: 43D-49D.

[3] Darien BJ, Godbee RJ (2009) Morinda citrifolia based formulations for regulating $\mathrm{T}$ cell immunomodulation in neonatal stock animals. USA Patent 20090068204.

[4] Ziauddin M, Phansalkar N, Patki P, Diwanay S, Patwardhan B (1996) Studies on the immunomodulatory effects of ashwagandha. J Ethnopharmacol 50: 69-76.

[5] Lukác N, Massányi P (2007) Effects of trace elements on the immune system. Epidemiol Mikrobiol Imunol 56: 3-9.

[6] Galland L (1998) Magnesium and immune function: An overview. Magnesium 7: 290 - 299.

[7] Wintergerst ES, Maggini S, Hornig DH (2007) Contribution of selected vitamins and trace elements to immune function. Ann Nutr Metab 51: 301-323.

[8] Girdhari L, Rana A (2007) Withania somnifera (Ashwagandha): A review. Pharmacogn Rev 1: 129-136.

[9] Owais M, Sharad KS, Shehbaz A, Saleemuddin M (2005) Antibacterial efficacy of Withania somnifera (Ashwagandha) an indigenous medicinal plant against experimental murine salmonellosis. Phytomedicine 12: 229-235. 
[10] Singh N, Bhalla M, de Jager P, Gilca M (2011) An overview on ashwagandha: A Rasayana (Rejuvenator) of Ayurveda. Afr J Tradit Complement Altern Med 8: 208-213.

[11] Mazumder PM, Pattnayak S, Parvani H, Sasmal D, Rathinavelusamy P (2012) Evaluation of immunomodulatory activity of Glycyrhiza glabra L roots in combination with zing. Asian Pac J Trop Biomed 2: S15-S20.

[12] Lutgendorf SK, Mullen-Houser E, Russell D, Degeest K, Jacobson G, Hart L, Bender D, Anderson B, Buekers TE, Goodheart MJ, Antoni MH, Sood AK, Lubaroff DM (2010) Preservation of immune function in cervical cancer patients during chemoradiation using a novel integrative approach. Brain Behav Immun 24: 1231-1240.

[13] Ironson G, Field T, Scafidi F (1996) Massage therapy is associated with enhancement of the immune system's cytotoxic capacity. Int J Neurosci 84: 205-217.

[14] Jain S, Hammerschlag R, Mills P, Cohen L, Krieger R, Vieten C, Lutgendorf S (2015) Clinical studies of biofield therapies: Summary, methodological challenges, and recommendations. Glob Adv Health Med 4: 58-66.

[15] Rubik B (2002) The biofield hypothesis: Its biophysical basis and role in medicine. J Altern Complement Med 8: 703-717.

[16] Trivedi MK, Patil S, Shettigar H, Mondal SC, Jana S (2015) The potential impact of biofield treatment on human brain tumor cells: A time-lapse video microscopy. J Integr Oncol 4: 141.

[17] Trivedi MK, Patil S, Shettigar H, Gangwar M, Jana S (2015) In vitro evaluation of biofield treatment on cancer biomarkers involved in endometrial and prostate cancer cell lines. J Cancer Sci Ther 7: 253-257.

[18] Trivedi MK, Patil S, Shettigar H, Mondal SC, Jana S (2015) In vitro evaluation of biofield treatment on Enterobacter cloacae: Impact on antimicrobial susceptibility and biotype. J Bacteriol Parasitol 6: 241.

[19] Trivedi MK, Patil S, Shettigar H, Mondal SC, Jana S (2015) Evaluation of biofield modality on viral load of hepatitis B and C Viruses. J Antivir Antiretrovir 7: 083-088.

[20] Trivedi MK, Patil S, Shettigar H, Mondal SC, Jana S (2015) An impact of biofield treatment: Antimycobacterial susceptibility potential using BACTEC 460/MGIT-TB System. Mycobact Dis 5: 189.

[21] Trivedi MK, Branton A, Trivedi D, Nayak G, Mondal SC, Jana S (2015) Antimicrobial sensitivity, biochemical characteristics and biotyping of Staphylococcus saprophyticus: An impact of biofield energy treatment. J Women's Health Care 4: 271.

[22] Trivedi MK, Branton A, Trivedi D, Nayak G, Mondal SC, Jana S (2015) Evaluation of antibiogram, genotype and phylogenetic analysis of biofield treated Nocardia otitidis. Biol Syst Open Access 4: 143.

[23] Trivedi MK, Branton A, Trivedi D, Nayak G, Charan S, Jana S (2015) Phenotyping and 16S rDNA analysis after biofield treatment on Citrobacter braakii: A urinary pathogen. J Clin Med Genom 3: 129.

[24] Trivedi MK, Patil S, Shettigar H, Bairwa K, Jana S (2015) Spectroscopic characterization of chloramphenicol and tetracycline: An impact of biofield. Pharm Anal Acta 6: 395.
[25] Trivedi MK, Patil S, Shettigar H, Bairwa K, Jana S (2015) Spectroscopic characterization of biofield treated metronidazole and tinidazole. Med Chem 5: 340-344.

[26] Trivedi MK, Patil S, Shettigar H, Bairwa K, Jana S (2015) Effect of biofield treatment on spectral properties of paracetamol and piroxicam. Chem Sci J 6: 98.

[27] Trivedi MK, Branton A, Trivedi D, Shettigar H, Bairwa K, Jana S (2015) Fourier transform infrared and ultravioletvisible spectroscopic characterization of biofield treated salicylic acid and sparfloxacin. Nat Prod Chem Res 3: 186.

[28] Trivedi MK, Branton A, Trivedi D, Nayak G, Gangwar M, Jana S (2016) Molecular analysis of biofield treated eggplant and watermelon crops. Adv Crop Sci Tech 4: 208.

[29] Trivedi MK, Branton A, Trivedi D, Nayak G, Mondal SC, Jana S (2015) Morphological characterization, quality, yield and DNA fingerprinting of biofield energy treated alphonso mango (Mangifera indica L.). Journal of Food and Nutrition Sciences 3: 245-250.

[30] Trivedi MK, Branton A, Trivedi D, Nayak G, Mondal SC, Jana S (2015) Evaluation of plant growth, yield and yield attributes of biofield energy treated mustard (Brassica juncea) and chick pea (Cicer arietinum) seeds. Agriculture, Forestry and Fisheries 4: 291-295.

[31] Trivedi MK, Branton A, Trivedi D, Nayak G, Mondal SC, Jana S (2015) Evaluation of plant growth regulator, immunity and DNA fingerprinting of biofield energy treated mustard seeds (Brassica juncea). Agriculture, Forestry and Fisheries 4: 269-274.

[32] Trivedi MK, Tallapragada RM, Branton A, Trivedi D, Nayak G, Jana S (2015) Characterization of physical and structural properties of aluminum carbide powder: Impact of biofield treatment. J Aeronaut Aerospace Eng 4: 142.

[33] Trivedi MK, Nayak G, Patil S, Tallapragada RM, Latiyal O, Jana $S$ (2015) Impact of biofield treatment on atomic and structural characteristics of barium titanate powder. Ind Eng Manage 4: 166.

[34] Trivedi MK, Patil S, Nayak G, Jana S, Latiyal O (2015) Influence of biofield treatment on physical, structural and spectral properties of boron nitride. J Material Sci Eng 4: 181.

[35] Trivedi MK, Nayak G, Patil S, Tallapragada RM, Latiyal O, Jana S (2015) Characterization of physical and structural properties of brass powder after biofield treatment. J Powder Metall Min 4: 134.

[36] Wu QL, Fu YF, Zhou WL, Wang JX, Feng YH, Liu J, Xu JY, He PL, Zhou R, Tang W, Wang GF, Zhou Y, Yang YF, Ding J, Li XY, Chen XR, Yuan C, Lawson BR, Zuo JP (2005) Inhibition of S-adenosyl-1-homocysteine hydrolase induces immunosuppression. J Pharmacol Exp Ther 313: 705-711.

[37] Madaan A, Kanjilal S, Gupta A, Sastry JL, Verma R, Singh AT, Jaggi M (2015) Evaluation of immunostimulatory activity of Chyawanprash using in vitro assays. Indian J Exp Biol 53: 158-163.

[38] Gao B, Radaeva S, Park O (2009) Liver natural killer and natural killer $\mathrm{T}$ cells: Immunobiology and emerging roles in liver diseases. J Leukoc Biol 86: 513-528. 
[39] Mohraz M, Khairandish P, Kazerooni PA, Davarpanah MA, Shahhosseiny MH, Mahdavian B, Vaziry S, Shahriary S, Kamali K, Khorram Khorshid HR, Heshmat R, Farhadi M, Gharibdoust F (2009) A clinical trial on the efficacy of IMOD in ADIS patient. DARU 17: 277-284.

[40] Mahmoodpoor A, Eslami K, Mojtahedzadeh M, Najafi A, Ahmadi A, Dehnadi-Moghadam A, Mohammadirad A, Baeeri M, Abdollahi M (2010) Examination of Setarud (IMOD ${ }^{\mathrm{TM}}$ ) in the management of patients with severe sepsis. DARU 18: 2328 .

[41] Singh D, Aggarwal A, Maurya R, Naik S (2007) Withania somnifera inhibits NF- $\kappa \mathrm{B}$ and $\mathrm{AP}-1$ transcription factors in human peripheral blood and synovial fluid mononuclear cells. Phytother Res 21: 905-913.

[42] Rayman MP (2000) The importance of selenium to human health. Lancet 356: 233-241.

[43] Ren F, Chen X, Hesketh J, Gan F, Huang K (2012) Selenium promotes T-cell response to TCR-stimulation and ConA, but not PHA in primary porcine splenocytes. PLoS One 7: e35375.

[44] Kruse-Jarres JD (1989) The significance of zinc for humoral and cellular immunity. J Trace Elem Electrolytes Health Dis 3: $1-8$.

[45] Abbas AK, Lichtman AH (2005) Cellular and Molecular Immunology, $5^{\text {th }}$ ed.; Elsevier Saunders: Philadelphia, PA, USA.

[46] Zhou X, Fragala MS, McElhaney JE, Kuchel GA (2010) Conceptual and methodological issues relevant to cytokine and inflammatory marker measurements in clinical research. Curr Opin Clin Nutr Metab Care 13: 541-547.

[47] Sugimoto J, Romani AM, Valentin-Torres AM, Luciano AA, Ramirez Kitchen CM (2012) Magnesium decreases inflammatory cytokine production: A novel innate immunomodulatory mechanism. J Immunol 188: 6338-6346.

[48] Feldman AM, Combes A, Wagner D, Kadakomi T, Kubota T, Li YY, McTiernan C (2000) The role of tumor necrosis factor in the pathophysiology of heart failure. J Am Coll Cardiol 35: $537-544$.

[49] MacEwan DJ (2002) TNF ligands and receptors - A matter of life and death. Br J Pharmacol 135: 855-875.
[50] Bradley JR (2008) TNF-mediated inflammatory disease. J Pathol 214: 149-160.

[51] Ren K, Torres R (2009) Role of interleukin-1 $\beta$ during pain and inflammation. Brain Res Rev 60: 57-64.

[52] Zhang J-M, An J (2007) Cytokines, inflammation and pain. Int Anesthesiol Clin 45: 27-37.

[53] Jesus AA, Goldbach-Mansky R (2014) IL-1 blockade in autoinflammatory syndromes. Annu Rev Med 65: 223-244.

[54] Ricciotti E, FitzGerald GA (2011) Prostaglandins and inflammation. Arterioscler Thromb Vasc Biol 31: 986-1000.

[55] Jacob F, Novo CP, Bachert C, Crombruggen KV (2013) Purinergic signaling in inflammatory cells: P2 receptor expression, functional effects, and modulation of inflammatory responses. Purinergic Signal 9: 285-306.

[56] Creswell JD, Irwin MR, Burklund LJ, Lieberman MD, Arevalo JM, Ma J, Breen EC, Cole SW (2012) Mindfulnessbased stress reduction training reduces loneliness and proinflammatory gene expression in older adults: A small randomized controlled trial. Brain Behav Immun 26: 10951101.

[57] Cole SW, Hawkley LC, Arevalo JM, Sung CY Rose RM, Cacioppo JT (2007) Social regulation of gene expression in human leukocytes. Genome Biol 8: R189.

[58] Durrieu G, Maury-Brachet R, Girardin M, Rochard E, Estuaries AB (2005) Contamination by heavy metals (Cd, Zn, $\mathrm{Cu}$, and $\mathrm{Hg}$ ) of eight fish species in the Gironde estuary (France). Estuaries 28: 581-591.

[59] Florento L, Matias R, Tuaño E, Santiago K, dela Cruz F, Tuazon A (2012) Comparison of cytotoxic activity of anticancer drugs against various human tumor cell lines using in vitro cell-based approach. Int J Biomed Sci 8: 76-80.

[60] Kahlenberg JM, Fox DA (2011) Advances in the medical treatment of rheumatoid arthritis. Hand Clin 27: 11-20.

[61] Dietrich J, Rao K, Pastorino S, Kesari S (2011) Corticosteroids in brain cancer patients: Benefits and pitfalls. Expert Rev Clin Pharmacol 4: 233-242. 